«Системні технології» 4 (123) 2019 «System technologies»

DOI 10.34185/1562-9945-4-123-2019-11

UDC 621.391 .175

L.D. Chumakov

\title{
SELECTION OF STRATEGY OF CONTROL OF GOOD STATE OF TECHNICAL SYSTEM WITH DUPLICATION OF CHANNELS AND VERIFICATION OF THEIR GOOD STATE ON THE BASIS OF GIVEN VALUE OF EFFICIENCY
}

Annotation. Modern technical systems contain, as a rule, a large amount of elements that may fail in the process of its operation.

To ensure high efficiency of the use of a technical system throughout the assigned lifetime, it is necessary to carry out its maintenance in order to identify possible failures and restore the up state of the system.

Discusses the issues of determining the duration of the interval between checks of the serviceable state of a technical system with duplication of channels and monitoring the health of each channel according to the criterion of a set value of availability function.

The possibility of approximate estimation, as well as the effect of the degree of approximation of the objective function on the efficiency of the use of the technical system, is investigated.

Studies have been carried out to determine the interval between checks of the technical system serviceability with duplication from the condition of meeting the requirements for its effectiveness.

It is shown that this approach can significantly reduce the number of checks compared with the optimal strategy and provide an economic effect.

Key words: technical system, channels, verification, control, strategy, elements.

Modern technical systems contain, as a rule, a large amount of elements that may fail in the process of its operation.

To ensure high efficiency of the use of a technical system throughout the assigned lifetime, it is necessary to carry out its maintenance in order to identify possible failures and restore the up state of the system.

One of the important operational characteristics of the system is the value of the inspection intervals, which is specified in the tactical and technical requirements. The developer needs to justify the implementation of these requirements.

As a rule, the developers solve the optimization problem.

$$
K_{a f}\left(\overline{\theta^{-}}\right)=\max _{\overline{\theta_{s} R}} K_{a f}(\bar{\theta}) \text {. }
$$

(C) Chumakov L.D., 2019 


\section{«Системні технології» 4 (123) 2019 «System technologies»}

where $\mathbf{K}_{\text {af }}(\bar{\theta})$ is the availability factor,

$\mathrm{R}$ is the area that defines the set of valid control strategies.

A significant number of publications, those include authors such as E.Yu. Barzilovich, V.F. Voskoboev, M.V. Savenkov, V.A. Kashtanov, V.D. Kudritsky, V.G. Kurasov, L.D. Chumakov et al.

Thus, in [1, 2], an expression was obtained for an approximate estimate of the optimal duration of the interval between checks $\theta^{\text {opt }}$ with an exponential distribution of the uptime:

$$
\theta^{\circ p t} \approx \sqrt{\frac{2 \tau}{\lambda_{w}}\left(1+\lambda_{c h} \tau_{r}\right)}
$$

where $\tau$ is the test duration, $\lambda_{\mathrm{w}}$ - failure rate when waiting, $\lambda_{\mathrm{ch}}$ - failure rate when checking, $\tau_{r}$ - replacement time.

In [3], an expression is given for $\theta^{\text {opt }}$ with the same waiting and checking mode, $\theta^{\text {опт }} \approx \sqrt{\frac{2 \tau}{\lambda}}$

However, this direction does not lose relevance, and research continues.

Usually, the curve of dependence of the availability factor values on the value of the inspection intervals in the optimum region has a gentle form and, consequently, the number of checks from the condition that the availability requirements are met can be reduced.

The purpose of the article is to show the solution to the problem of choosing the duration of intervals between checks for this case. A similar problem for a system without redundancy was solved in work [4].

In this article a technical system is considered, which is in a state of readiness to accomplish the task set for it on an interval [T], where $\mathrm{T}$ is the assigned lifetime.

At a random moment of time, evenly distributed over the interval, a command may be received to use the technical system. At the same time, there may be a hidden failure according to some set of parameters that determine the efficiency of the system. To eliminate it, checks are performed on the technical system. Different groups of parameters can be monitored continuously, periodically or not monitored over the entire life cycle. The tasks of evaluating the efficiency of operating a technical system with the aggregate repair method are considered in works [5, 6].

In our case, periodic good state monitoring is considered. We assume that the control strategy is determined by the vector of intervals between checks $\bar{\theta}$. 


\section{«Системні технології» 4 (123) 2019 «System technologies»}

Let's the uptime be distributed according to the exponential law where $\lambda$ is the channel failure rate. For a system without a reserve, the optimal control strategy is a uniform arrangement of checks [1-3], so in our case one inspection interval can be considered.

The expression for the availability of the system with duplication of channels, assuming that the replacement time is negligible, we write as follows:

$$
K_{a f}(\theta)=\frac{2\left(1-e^{-\lambda \theta}\right)-0,5\left(1-e^{-2 \lambda \theta}\right)}{\lambda(\theta+\tau)} .
$$

Denote $\mathbf{K}_{\text {af }}^{s}$ the set value of availability factor, and then the selection condition for the quantity $\theta^{*}$ is:

$$
K_{a f}\left(\theta^{*}\right)=K_{a f}^{s}
$$

An approximate solution of the problem can be searched for by expanding the exponents in a series and taking a different number of expansion terms.

Formula (3) will be as follows: for three members of expansion:

$$
K_{a f}(\theta)=\frac{\theta-\frac{\lambda^{2} \theta^{3}}{3}}{\theta+\tau} \text {; }
$$

for four members of expansion:

$$
K_{a f}(\theta)=\frac{\theta-\frac{\lambda^{2} \theta^{3}}{3}+\frac{\lambda^{2} \theta^{4}}{4}}{\theta+\tau} ;
$$

for five members of expansion:

$$
K_{a f}(\theta)=\frac{\theta-\frac{\lambda^{2} \theta^{3}}{3}+\frac{\lambda^{3} \theta^{4}}{4}-\frac{2 \lambda^{4} \theta^{5}}{15}}{\theta+\tau} .
$$

Let's the channel of system consist of one computer with a failure rate of $\lambda=$ $0.86491 / \mathrm{Y}$. The recovery time of the system is $\tau=0.0044 \mathrm{Y}$. [4]. With an optimal control strategy, $\mathbf{K}_{\mathrm{aff}}(\theta$ opt $)=0.9176$. If it is required to ensure $\mathbf{K}_{\mathbf{a f}}^{s}=0.95$, then in this case it is necessary to apply channel redundancy, for example, duplication.

We investigate the dependence of the system efficiency on the control strategy. The graphs of the dependence of the system availability factor on the number of checks on the assigned lifetime, built on the basis of the formulas $(3,5-7)$ are shown in figure.

We write expressions for equations, from which it is possible to calculate the value of the interval between checks.

Using expression (5), we obtain the following equation:

$$
\lambda^{2} \theta^{2}-3\left(1-K_{a f}^{g}\right) \theta+3 K_{a f}^{g} \tau=0 \text {. }
$$


«Системні технології» 4 (123) 2019 «System technologies»

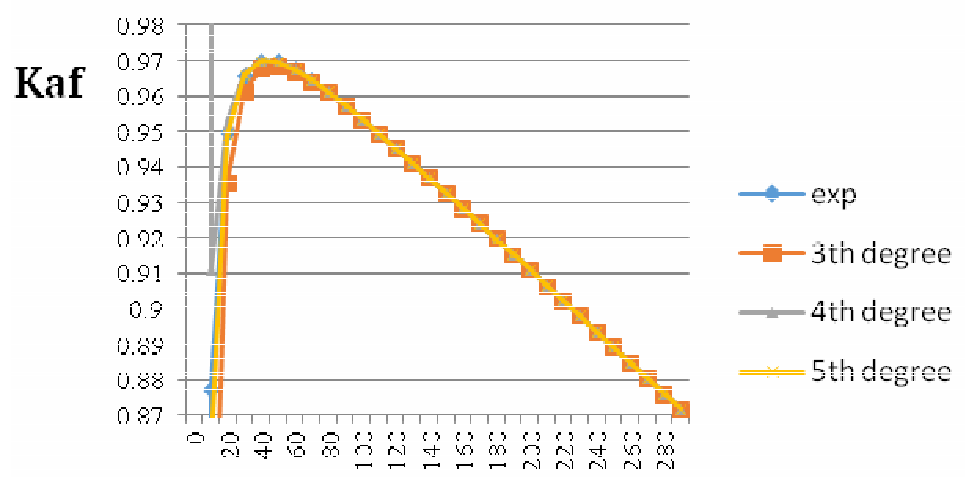

Number of checks

Figure 1 - Dependence of availability factor on the number of checks

For the expression (6), then the equation will have the following form:

$3 \lambda^{3} \theta^{4}-4 \lambda^{2} \theta^{3}+12\left(1-K_{a f}^{g}\right) \theta-12 K_{a f}^{g} \tau=0$.

For the expression (7), we obtain the equation of the 5th degree:

$$
3 \lambda^{4} \theta^{5}-15 \lambda^{5} \theta^{4}+20 \lambda^{2} \theta^{5}-60\left(1-K_{a f}^{g}\right) \theta+60 K_{a f}^{g} \tau=0 \text {. }
$$

The solution of such equations causes certain difficulties; however, algorithms have been developed that allow finding their solutions [7]. The best approximate solutions are obtained by using the expression (10).

The values of the required and optimal intervals between the checks for our example are given in the table 1.

Table 1

Values of inspection intervals and availability factors

\begin{tabular}{|c|c|c|c|c|c|}
\hline The equation & $\theta^{*} \mathrm{Y}$. & $\theta^{\text {opt }} \mathrm{Y}$. & $K_{a f}\left(\theta^{*}\right)$ & $K_{a f}\left(\theta^{\text {opt }}\right)$ & $\theta^{*} / \theta^{\text {opt }}$ \\
\hline Exponents & 0,47 & 0,219 & 0,95 & 0,9701 & 2,1 \\
\hline 3rd degree & 0,4 & 0,203 & 0,9497 & 0,9687 & 1,97 \\
\hline 4th grade & 0,5 & 0,222 & 0,9495 & 0,9702 & 2,25 \\
\hline 5th degree & 0,47 & 0,219 & 0,9492 & 0,9701 & 2,1 \\
\hline
\end{tabular}

Thus, the refusal to assign the optimum values of inspection intervals and the use of intervals that ensure a given level of readiness can reduce the number of checks and reduce the cost of operation several times.

Conclusions. Studies have been carried out to determine the interval between checks of the technical system serviceability with duplication from the condition of meeting the requirements for its effectiveness.

It is shown that this approach can significantly reduce the number of checks compared with the optimal strategy and provide an economic effect. 


\section{«Системні технології» 4 (123) 2019 «System technologies»}

\section{ЛИТЕРАТУРА / ЛІТЕРАТУРА}

1. Чумаков Л.Д. Оценка периодичности проверок ракетного комплекса, находящегося на боевом дежурстве, при проектировании // Тр. СВВКУ, Саратов, СВВКУ, 1969, C.31-32.

2. Барзилович Е.Ю. Оптимизация периодичности контроля систем, недоступных непрерывным проверкам // Автоматика и телемеханика - 1969. - №8. - С.175-177.

3. Чумаков Л.Д. Оптимизация стратегии контроля исправности хранящейся системы // Сб. "Надежность сложных технических систем". - К. : Наук. думка, 1974 - С.36-43.

4. Чумаков Л.Д. Выбор стратегии контроля исправности технической системы на основе заданной эффективности // Системные технологии. Региональный межвузовский сборник научных работ. - Выпуск 5(118). - Днепропетровск, 2018. - С.179-183.

5. Чумаков Л.Д. Коэффициент готовности, стоимость эксплуатации технического устройства при комбинированном контроле и различной интенсивности восстановления его работоспособности // Сб. "Прочность и надежность технических устройств". - К. : Наук. думка, 1981 - С.162-171.

6. Переверзев Е.С., Чумаков Л.Д. Параметрические модели отказов и методы оценки надежности технических систем / отв. ред. В.С. Будник. - АН УССР. Институт технической механики. - К.: Наук. думка, 1989-184 с.

7. Вычисление корней полинома [Электронный ресурс] - Электрон. дан. - Режим доступа: https://planetcalc.ru/7765/, свободный - Загл. с экрана.

\section{REFERENCES}

1. Chumakov L.D. Otsenka periodichnosti proverok raketnogo kompleksa, nahodyaschegosya na boevom dezhurstve, pri proektirovanii // Tr. SVVKU, Saratov, SVVKU, 1969, S.31-32.

2. Chumakov L.D. Optimizatsiya strategii kontrolya ispravnosti hranyascheysya sistemyi // Sb. "Nadezhnost slozhnyih tehnicheskih sistem". - K. : Nauk. dumka, 1974 - S.36-43.

3. Barzilovich E.Yu. Optimizatsiya periodichnosti kontrolya sistem, nedostupnyih nepreryivnyim proverkam // Avtomatika i telemehanika - 1969. \#8. - S.175-177.

4. Chumakov L.D. Vyibor strategii kontrolya ispravnosti tehnicheskoy sistemyi na osnove zadannoy effektivnosti // Sistemnyie tehnologii. Regionalnyiy mezhvuzovskiy sbornik nauchnyih rabot. - Vyipusk 5(118). - Dnepropetrovsk, 2018. - S.179-183.

5. Chumakov L.D. Nadezhnost, stoimost ekspluatatsii tehnicheskogo ustroystva pri kombinirovannom kontrole ispravnosti i vozmozhnosti oshibok kontroliruyuschey apparaturyi // Sb. "Prochnost i dolgovechnost konstruktsiy". - K. : Nauk. dumka, 1980 - S.174-183.

6. Chumakov L.D. Koeffitsient gotovnosti, stoimost ekspluatatsii tehnicheskogo ustroystva pri kombinirovannom kontrole i razlichnoy intensivnosti vosstanovleniya ego rabotosposobnosti // Sb. "Prochnost i nadezhnost tehnicheskih ustroystv". - K. : Nauk. dumka, 1981 - S.162-171.

7. Pereverzev E.S., Chumakov L.D. Parametricheskie modeli otkazov i metodyi otsenki nadezhnosti tehnicheskih sistem / otv. red. V.S. Budnik. AN USSR. Institut tehnicheskoy mehaniki. - K. : Nauk. dumka, 1989. - 184 s. 


\section{«Системні технології» 4 (123) 2019 «System technologies»}

8. Vyichislenie korney polinoma [Elektronnyiy resurs] - Elektron. dan. - Rezhim dostupa: https://planetcalc.ru/7765/, svobodnyiy - Zagl. s ekrana.

Received 11.03.2019. Accepted 15.03.2019.

\section{Выбор стратегии контроля исправности технической системы с дублированием} каналов и проверкой их исправности на основе заданной эффективности

Современные технические системы содержат, как правило, большое количество элементов, которые могут отказывать в процессе ее эксплуатации.

Для обеспечения высокой эффективности использования технической системы в течение всего назначенного срока эксплуатации необходимо проводить ее техническое обслуживание с целью выявления возможных отказов и восстановления работоспособного состояния системы.

Обсуждаются вопросы определения длительности интервала между проверками исправного состояния технической системы с дублированием каналов и контролем исправности каждого канала по критерию заданной величины коэффициента готовности.

Исследована возможность приближенной оценки, а также влияние степени приближения целевой функции на эффективность использования технической системы.

Проведены исследования определения величины интервала между проверками исправности каналов технической системы с дублированием из условия выполнения требований кее эффективности.

Показано, что этот подход может значительно сократить число проверок по сравнению с оптимальной стратегией и дать экономический эффект.

\section{Вибір стратегії контролю справності технічної системи з дублюванням каналів $i$} перевіркою їх справності на основі заданої ефективності

Сучасні технічні системи містять, як правило, велика кількість елементів, які можуть відмовляти в процесі її експлуатації.

Для забезпечення високої ефективності використання технічної системи протягом усього призначеного терміну експлуатації необхідно проводити іï технічне обслуговування 3 метою виявлення можливих відмов і відновлення працездатного стану системи.

Обговорюються питання визначення тривалості інтервалу між перевірками справного стану технічної системи з дублюванням каналів і контролем справності кожного каналу за критерієм заданої величини коефіцієнта готовності.

Досліджено можливість наближеної оцінки, а також вплив ступеня наближення цільової функції на ефективність використання технічної системи.

Проведено дослідження визначення величини інтервалу між перевірками справності каналів технічної системи з дублюванням за умови виконання вимог до її ефективності.

Показано, що цей підхід може значно скоротити кількість перевірок у порівнянні $з$ оптимальною стратегією і дати економічний ефект.

Чумаков Л.Д. - профессор кафедры компьютерно-интегрированных технологий и автоматизации Украинского государственного химико-технологического университета.

Чумаков Л.Д. - професор кафедри комп'ютерно-інтегрованих технологій i автоматизації Українського державного хіміко-технологічного університету.

Chumakov L.D. - Professor, Department of Computer-integrated Technologies and Automation, Ukrainian State University of Chemical Technology. 